\title{
ATM Monoallelic Inactivation
}

National Cancer Institute

\section{Source}

National Cancer Institute. ATM Monoallelic Inactivation. NCI Thesaurus. Code C150584.

The presence of mutations in only one allele of the ATM gene that either lead to decreased of expression of the AT M protein or result in the translation of an inactive and potentially dominant-negative form of the ATM protein. 